\title{
Portrayal of psychiatric genetics in Australian print news media, 1996-2009
}

\section{Alex Wilde BSc(Hons),PhD, Research Associate \\ Catriona Bonfiglioli BA(Hons), PhD, Senior Lecturer in Media Studies ${ }^{2}$}

Bettina Meise PhD, Associate Professor

Philip B Mitchell AM, MD Scientia Professor and Head

Peter R Schofield PhD, DSC

Executive Director and CEO

1 School of Psychiatry, University of New South

Wales, Sydney, NSW.

2 Journalism, Information and Media Studies Group, University of Technology,

Sydney, Sydney, NSW.

3 Prince of Wales Clinical School, University of New South Wales, Sydney, NSW.

4 Neuroscience Research

Australia, Sydney, NSW.

alex.wilde@unsw.edu.au

MJA 2011; 195: 401-404 doi: 10.5694/mjal0.10167 in he mass media are a key source of health and science information for the lay public. ${ }^{1,2}$ Medical genetics has received substantial coverage in the international media over the past few decades, with greater intensity of coverage appearing to coincide with announcements of discoveries of new susceptibility genes. ${ }^{1}$ Media discourse about genetics and mental illness has been negligible.

Medical issues are placed higher on the public and political agenda when they receive intense coverage in the media. ${ }^{3}$ Journalists' choice of news angle and scientists' selective emphasis of certain aspects of their research contribute to framing and help push an issue higher up the news agenda. Analysing news frames thus offers a way to systematically examine the likely influence of media agendas on public thinking. ${ }^{4}$

Previous analyses of genetic news identified genetic determinism (eg,

\section{Definitions \\ Media framing: the way in which journalists' choice of angle, sources and quotes highlights some issues and sidelines others, thus defining problems, assigning causes and attributing responsibility. ${ }^{4}$ \\ Genetic frames \\ - Genetic determinism: portrays genes as the cause of disease and may overstate the role of susceptibility genes linked to mental illnesses ${ }^{5,6,8}$ - eg, "gene for schizophrenia is found". \\ - Probabilistic framing: portrays genes as conferring a susceptibility to illness ${ }^{8}$ - eg,"genetic predisposition to depression". \\ Prophetic frames \\ - Genetic optimism: emphasises a positive impact of the role of genetic technologies ${ }^{1}$ - eg, "the identification of genes will enable new treatments". \\ - Genetic pessimism: presents the impact of genetic research on society as leading to a social dystopia' - eg, "fear that discovery of genes will lead to a genetic underclass".}

Causal attributions for mental illness: genetic and/or environmental factors or gene-environment interactions perceived as contributing to the development of mental illness.

\section{Abstrac \\ Objective: To investigate how Australian print news media portray psychiatric} genetics.

Design and setting: Content and framing analysis of a structured sample of print news items about psychiatric genetics published in Australian newspapers between 1996 and 2009.

Main outcome measures: Identify dominant discourses about aetiology of mental illness, and perceived clinical outcomes and implications of psychiatric genetics research.

Results: We analysed 406 eligible items about the genetics of psychiatric disorders. News coverage of psychiatric genetics has steadily increased since 1996. Items attributing the aetiology of psychiatric disorders to geneenvironment interactions (51\%) outnumbered items attributing only genetic $(30 \%)$ or only environmental factors $(20 \%)$. Of items that referred to heritability of mental illness, frames of genetic determinism (78\%) occurred more frequently than probabilistic frames (22\%). Of frames related to genetic prophesy, genetic optimism frames (78\%) were used more frequently than frames of genetic pessimism (22\%). Psychosocial and ethical implications of psychiatric genetics received comparatively relatively little coverage $(23 \%)$. The analysis identified 22 predictions about psychiatric genetic discoveries and the availability of molecular-based interventions in psychiatry, most of which (20/ $22,91 \%$ ) failed to manifest by the predicted year.

Conclusions: Excessive optimism about the power of genetic technology in psychiatric health care, perceived clinical benefits, and largely unfulfilled predictions about availability of these benefits could encourage unrealistic expectations about future molecular-based treatment options for mental health.

Mendelian inheritance), ${ }^{5-7}$ genetic optimism $^{1}$ and genetic pessimism ${ }^{1}$ as important agenda-setting frames (Box 1). In the United States news media, genetic determinism is reported to have decreased, giving way to the domination of genetic optimism frames. ${ }^{1,9}$ Undue media optimism is not limited to medical genetics research. Misleading reporting of novel therapies for cancer offering unrealistic hope is a high-profile example. ${ }^{10,11}$

The present study aimed to qualitatively analyse news articles about the role of genes in depression, bipolar disorder and schizophrenia in the Australian print media by mapping the use of the frames of genetic determinism, genetic optimism and genetic pessimism. We hypothesised that (i) probabilistic framing (eg, susceptibility genes) would be more prevalent than deterministic framing, and (ii) that the frame of genetic optimism would be used more frequently than that of genetic pessimism.

\section{Methods}

Relevant newspaper articles were systematically identified on the Factiva database (Dow Jones, http:// www.factiva.com) via date-limited keyword searches from 1 January 1996 to 31 Dec 2006 and later updated to 31 Dec 2009, using a keyword formula: (depression or bipolar or (manic depression) or schizophrenia) and (gene or genes or genet* or DNA).

News stories were examined using content $^{12,13}$ and frame analysis. ${ }^{4}$ After removal of duplicates, off-topic articles and articles only briefly mentioning psychiatric genetics, items were judged to be eligible for analysis and studied for relevant content.

\section{Data analysis}

A conceptually clustered, 23-item coding tree was developed (AW) according to widely accepted standards of qualitative methodology. ${ }^{14}$ Whole articles were assigned codes for publication, year of publication, 
page number and psychiatric disorder(s). Transcripts were then subcoded by paragraph ${ }^{1,4,12}$ according to six main content and framing codes: causal attributions; genetic frames (deterministic, probabilistic); prophetic frames (optimistic, pessimistic); psychosocial and ethical issues; perceived clinical outcomes (of psychiatric genetic research); and media predictions.

\section{Interrater reliability}

Ten per cent of the sample was informally recoded (BM) to identify any discrepancies in the interpretation of codes. The coding instrument was then refined by merging, deleting, or inserting codes, and revising coding descriptions until the informal assessment suggested an adequate level of agreement by consensus. ${ }^{15}$

Ten per cent of the sample was double-coded (C B) to allow for a formal intercoder reliability assessment. This coding was performed independently and without consultation or guidance. Cohen's kappa was used to calculate interrater reliability $^{15,16}$ and yielded a kappa coefficient of 0.68 (SD, 0.25), which represents good agreement beyond chance for a 23 -item coding tree. ${ }^{17}$

Coded articles were subsequently analysed for existing and emergent frames using QSR N6 software (QSR International, Melbourne, Vic) ${ }^{18}$ according to the methods described by Miles and Huberman. ${ }^{19}$ This facilitated comparisons between articles from different publications and years as well as other aspects of the analysis. The conceptual approaches of Entman ${ }^{4}$ and Scheufele ${ }^{12}$ were used to guide the framing analysis.

\section{Results}

The systematic database search retrieved 3623 news items. Exclusion of ineligible articles resulted in a final sample of 406 news items across 14 Australian news publications from 1996 to 2009.

We found that the number of items about psychiatric genetics increased steadily over the 14-year period, with more than 50\% appearing since 2005 .

Peaks in coverage coincided with the publication of the Human Genome Project in 2001 and the upsurge of direct-to-consumer genetic tests for risk of mental disorders during 2007-2008.

In relation to genetics and mental illness, depression featured the most frequently in the sample (199/406 items, $49 \%)$, followed by schizophrenia (181/406 items, 45\%) and bipolar disorder or "manic depression" (83/406 items, 20\%). Some items included more than one of the three target disorders.

\section{Causal attributions}

Content analysis found that perceived causes of mental illness (354/406 items, $87 \%$ ) were a dominant theme (Box 2).

The dominant discourse about aetiology of depression, bipolar disorder and schizophrenia focused on interaction between genetic and environmental risk factors (179/354 items, $51 \%)$. Gene-environment interactions tended to be framed as a genetic predisposition with environmental factors acting as triggers: "If you want to know if you have a genetic disposition to schizophrenia or other mental illness, indulge in cannabis because it will trigger it." 20

Portrayal of genetic aetiology of mental illness (105/354, 30\%) focused on one or more genes, genetic variants or gene expression: "The mystery of schizophrenia is being unravelled, with a breakthrough identifying a number of genes that may cause the disorder." 21

Of items that attributed the aetiology of mental illness to environmental factors alone $(70 / 354,20 \%)$, stressful life events $(17 / 70,24 \%)$ were presented as the dominant factor: "The biggest ... cause [of depression] is probably a life experience such as the death of a loved one, loss of a job or repeated bullying." 22

Nineteen other environmental causal attributions identified in the sample were financial strain, global financial crisis, victim of crime, natural disaster, lack of social support, viruses, child abuse or neglect, poverty, drug and alcohol use, comorbidities, insomnia, coping styles, uterine environment, parental age at conception, postnatal adjustment disorders, family environment, trauma, virtual stalking, and "contemporary society".
2 Media framing of genetics, mental illness and its causes, 1996-2009 $(n=406)$

Causal attributions

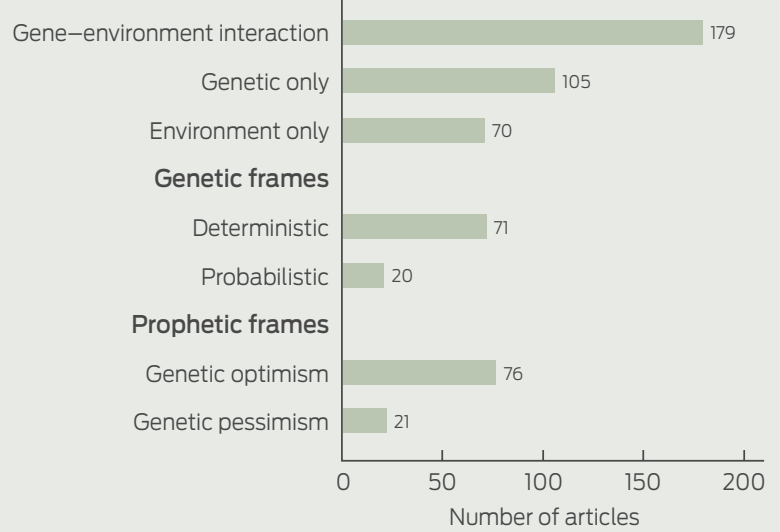

\section{Genetic frames}

Ninety-one of 406 items (22\%) carried messages about the role of genes in the development of mental illness (Box 2). Of these, genetic determinism was the dominant frame (78\%): "In a world first, researchers from NSW have discovered the gene responsible for depression." 23

Twenty of the 91 items (22\%) framed the role of genes as probabilistic rather than deterministic: "[Dr Tiller said] having a genetic predisposition to [depression] did not mean it was expressed." 24

Contrary to our first hypothesis, we found that the frequency of reports using deterministic framing (78\%) was greater than that of reports that used probabilistic framing (22\%).

\section{Prophetic frames}

Ninety-seven of 406 items (24\%) used optimistic or pessimistic frames. Of these, frames of genetic optimism $(78 \%)$ were used more frequently than frames of genetic pessimism (22\%) (Box 2).

Common optimistic discourse used the terms "hope", "world first" and "breakthrough", and often alluded to the perceived positive impact of genetic discoveries on future treatment options: "For the first time, researchers have hard evidence that genetic mutations in the immune system are linked to schizophrenia ... the findings provide hope of better treatment for the devastating psychiatric disorder ..." 25

Pessimistic discourse about genes and mental illness focused on neg- 


\begin{tabular}{|c|c|c|c|c|}
\hline Prediction & Year made & $\begin{array}{l}\text { Year expected } \\
\text { to occur }\end{array}$ & Outcome of prediction ${ }^{28}$ & Publication \\
\hline $\begin{array}{l}\text { "Professor Grant Sutherland ... says: 'There will, in the next } \\
10 \text { to } 15 \text { years, be a whole range of these susceptibility } \\
\text { genes that are identified for many of the common diseases } \\
\text {... of aging, which will include ... depression ..." }\end{array}$ & 1998 & $2008-2013$ & $\begin{array}{l}\text { Depression susceptibility gene replicated } \\
2003-2009 ; \text { scientific validity still being } \\
\text { researched in } 2011^{29}\end{array}$ & $\begin{array}{l}\text { Hill K, Dayton L. How genetic } \\
\text { secrets could cure the baby } \\
\text { boomers. Sydney Morning Herald } \\
\text { 1998; } 31 \text { Mar: } 1\end{array}$ \\
\hline $\begin{array}{l}\text { "The head of the Human Genome Project, Francis Collins, } \\
\text { predicts that it will take up to seven years to locate the } \\
\text { genes that cause ... manic depression." }\end{array}$ & 2000 & 2007 & No causal genes identified by 2011 & $\begin{array}{l}\text { Alcorn G. Genome mappers join } \\
\text { last of mankind's dots. The Age } \\
\text { (Melbourne) 2000; } 24 \text { Jun: } 1\end{array}$ \\
\hline $\begin{array}{l}\text { "Creation of a successful test [suicide prediction } \\
\text { associated with antidepressant use] ... may lead to more } \\
\text { careful treatment of depressed patients who carry the } \\
\text { mutation." }\end{array}$ & 2000 & 2002 & $\begin{array}{l}\text { Not clinically available in } 2011 \text {; became } \\
\text { available commercially direct-to- } \\
\text { consumer in } 2007 \text {; withdrawn in } 2008\end{array}$ & $\begin{array}{l}\text { O'Neill G. Gene linked to suicide } \\
\text { risk. Herald Sun (Melbourne) } \\
\text { 2000; } 30 \text { Jan: } 14\end{array}$ \\
\hline $\begin{array}{l}\text { "[Dr Collins said] predictive genetic tests would be } \\
\text { available for dozens of diseases." }\end{array}$ & 2001 & 2010 & $\begin{array}{l}\text { Commercial "whole genome" scanning } \\
\text { became available direct-to-consumer } \\
\text { by } 2007\end{array}$ & $\begin{array}{l}\text { Chapman J. Genetically modified } \\
\text { man within } 30 \text { years. The } \\
\text { Advertiser (Adelaide) 2001; } 10 \\
\text { Feb: } 52\end{array}$ \\
\hline $\begin{array}{l}\text { "[Australian scientists have] identified about } 60 \text { genes } \\
\text { that are almost definitely involved in [schizophrenia] ... } \\
\text { [any new drugs] could be expected on the market within } \\
\text { six to eight years." }\end{array}$ & 2004 & 2010-2012 & $\begin{array}{l}\text { Pharmacogenetic treatment for } \\
\text { schizophrenia unavailable by } 2011\end{array}$ & $\begin{array}{l}\text { AAP. Schizophrenia genes found. } \\
\text { The Mercury (Hobart) 2004; } 17 \\
\text { Jan: } 12\end{array}$ \\
\hline $\begin{array}{l}\text { "... researchers predict gene tests for predisposition to ... } \\
\text { schizophrenia ... will also be on offer in five to } 10 \text { years." }\end{array}$ & 2004 & 2009-2014 & Unavailable by 2011 & $\begin{array}{l}\text { Kelly J. Gene tests to predict } \\
\text { diseases. Herald Sun } \\
\text { (Melbourne) 2004; } 29 \text { Jul: } 27\end{array}$ \\
\hline $\begin{array}{l}\text { "Twenty-minute [genetic] tests leading to better } \\
\text { medication prescriptions [for schizophrenia] should be } \\
\text { available." }\end{array}$ & 2005 & 2007-2008 & Unavailable by 2011 & $\begin{array}{l}\text { Livingstone T. Heredity of } \\
\text { addiction linked to schizophrenia. } \\
\text { Courier Mail (Brisbane) 2005: } 16 \\
\text { Mar; } 38\end{array}$ \\
\hline $\begin{array}{l}\text { "Within a decade, it is predicted, the cost will drop far } \\
\text { enough for everyone to have their own genetic code } \\
\text { sequenced." }\end{array}$ & 2007 & 2017 & $\begin{array}{l}\text { By } 2011 \text {, discount } 23 \text { gene-disease- } \\
\text { association "scans" were available } \\
\text { direct-to-consumer for about US } \$ 399\end{array}$ & $\begin{array}{l}\text { Smith D. The genome let out of } \\
\text { the bottle. Sydney Morning Herald } \\
\text { 2007; } 7 \text { Jun: } 12\end{array}$ \\
\hline
\end{tabular}

ative impact of labelling, negative political agenda, and increase of stigma and/or risk of eugenics: "Genetic testing [for a mental illness] seems certain to allow doctors to predict which diseases patients are likely to develop years before they show symptoms - raising the prospect of a 'genetic underclass' ..." 26

\section{Psychosocial and ethical issues}

Discourse about ethical and social implications of psychiatric genetic testing occurred in 95 of 406 items (23\%). These implications included stigma, threat to privacy of genetic information, equity of access to genetic services, eugenics, genetic discrimination by employers and insurance companies, the right to know or not to know one's genetic information, impact on relatives and risk of distress.

\section{Perceived clinical outcomes of genetic research}

One hundred and seventy-five items (43\%) reported six potential clinical outcomes of genetic research in psychiatry: preventive interventions (50/ $175,29 \%)$; pharmacogenetics (49/175, $28 \%)$; predictive genetic testing (44/ $175,25 \%)$; gene therapy $(13 / 175,7 \%)$; improved treatments and technology (11/175, 6\%) and personalised medi- cine $(8 / 175,5 \%)$. As noted above, potential clinical outcomes were predominantly framed in terms of genetic optimism: "If people know that they have a genetic susceptibility it may become possible to avoid episodes of mania or depression by monitoring and treating early changes in brain chemistry, or by trying to reduce environmental triggers, such as stress ..."27

\section{Media predictions}

We identified 22 media predictions that consisted of specific temporal predictions about future genetic discoveries and availability of genetic-based psychiatric services (Box 3). Predictions focused on future identification of genes involved in psychiatric disorders $(9 / 22,41 \%)$, introduction of psychiatric genetic tests $(7 / 22,32 \%)$, prenatal genetic diagnoses for depression or schizophrenia $(2 / 22,9 \%)$, pharmacogenetic services (2/22, 9\%); geneticbased insurance evaluation $(1 / 22,5 \%)$, and availability of low-cost personal genome sequencing $(1 / 22,5 \%)$.

Most predictions $(20 / 22,91 \%)$ failed to occur by $2011 .^{28}$ Two items accurately predicted in 1998 and 2001, respectively, that genetic tests or genome sequencing involving psychiatric disorders would be available by 2010. Such tests became available by about 2007 via unregulated commercial direct-to-consumer services, although many have since been withdrawn. ${ }^{30}$

\section{Discussion}

This is the first systematic analysis of Australian news depictions of psychiatric genetics. The rapid rise in the quantity of media coverage about genetic advances in psychiatry since 1996 suggests that the subject is gaining importance on public and political agendas. The finding that peaks in media coverage of genetic advances coincided with significant scientific announcements is consistent with previous observations. $^{1}$

Deterministic framing was more frequent than probabilistic framing, in contrast to our first hypothesis. The need for editorial brevity can pressure journalists to transform complex concepts about genetic penetrance in multifactorial disorders into shorter more accessible deterministic statements, with the risk of distorting meanings. The predominance of portrayals of the contribution of both genetic and environmental factors to psychiatric disorders contradicts earlier research, which found that the influence of non-genetic factors and/or 
gene-environment interactions was rarely mentioned. ${ }^{31}$ However, in the present study, messages about the power of the genetic component were primarily deterministic, which suggests that the public may be misinformed about the complexities of the genetic underpinnings of mental illness and their interaction with the environment.

The genetic optimism frame predominantly described utopian expectations of molecular-based future treatment for psychiatric disorders; in particular, preventive interventions, pharmacogenetics and genetic testing. It has been proposed ${ }^{31}$ that it is not only editors and journalists who set the agenda underpinning positive images about the clinical benefits resulting from genetic research. Scientists' commercial interests are emerging as a source of positive bias in medical reporting, ${ }^{32,33}$ although this was not investigated in our study. Negative images of genetic research, such as reports of regular failures to replicate genetic associations with certain diseases, ${ }^{1}$ and items with negative messages about eugenics, were less frequent than optimistic messages. This finding supports our second hypothesis that the frame of genetic optimism would be used more frequently than that of genetic pessimism.

The high prevalence of overpromising of clinical benefits from psychiatric genetic research is consistent with the results of previous research. ${ }^{1,31}$ This is likely to reflect journalists' inclinations to cover news from highimpact journals, which tend not to publish negative studies. ${ }^{1}$ Because the news media are a major source of public knowledge of genetics, optimistic framing may distort public understanding of the influence of genes in multifactorial disease and future options for preventing, treating and managing mental illness.

The low frequency of items about social and ethical issues, such as the potential for genetic discrimination by employers or insurance companies, suggests that the social and ethical implications of psychiatric genetics research are a low priority on the public and political agenda. ${ }^{3}$ This could potentially have negative consequences for individuals affected by depression, bipolar disorder or schizophrenia.

Before drawing any conclusions about the full spectrum of media representation of psychiatric genetics, portrayals in other media formats should be investigated. Contrary to recommendations, ${ }^{13}$ our formal coder was not blind to the purpose of the study and the research question guiding the investigation. This was unavoidable, given the complexity of the coding tree and the necessity that the coder should fully understand the variables and their descriptors. Systematic analysis of how frames vary with article quality would help to further determine whether there is a mismatch between scientific understanding and medical reporting.

Our study has shown that there is a lack of balance between the perceived positive outcomes of psychiatric genetic research and critical commentaries about potential ethical and social implications. Optimistic predictions about the use of genetic information in psychiatry could encourage unrealistic public expectations about how future mental health problems might be solved.

Acknowledgements: We thank Nadine Kasparian for training in the use of QSR N6 software and Dusan HadziPavlovic for training in calculating interrater reliability. This study was supported by a National Health and Medical Research Council (NHMRC) Public Health PhD Scholarship (455414), an NHMRC Career Development Award (350989) and an NHMRC Program Grant (510135).

Competing interests: No relevant disclosures.

Received 16 Feb 2010, accepted 18 Mar 2011.

1 Conrad P. Genetic optimism: framing genes and mental illness in the news. Cult Med Psychiatry 2001; 25: 225-247.

2 Wade S, Schramm W. The mass media as source of public affairs, science, and health knowledge. Public Opinion O 1969; 33: 197-209.

3 Bonfiglioli CMF, Smith BJ, King LA, et al. Choice and voice: obesity debates in television news. Med J Aust 2007; 187: 442-445.

4 Entman RM. Framing: toward clarification of a fractured paradigm. J Commun 1993; 43: 51-58.

5 Nelkin D, Lindee M. The DNA mystique: the gene as a cultural icon. New York: Freeman, 1995.

6 Hubbard R, Wald E. Exploding the gene myth: how genetic information is produced and manipulated by scientists, physicians, employers, insurance companies, educators, and law enforcers. New York: Beacon, 1993.

7 Conrad P. Weinberg D. Has the gene for alcoholism been discovered three times since 1980? A news media analysis. Perspect Soc Problems 1996; 8: 3-25.

8 Condit CM, Ofulue N, Sheedy KM. Determinism and mass-media portrayals of genetics. Am J Hum Genet 1998; 62: 979-984.
9 Holtzman NA, Bernhardt BA, Mountcastle-Shah $E$, et al. The quality of media reports on discoveries related to human genetic diseases. Community Genet 2005; 8: 133.

10 Daugherty CK. The "cure" for cancer: can the media report the hope without the hype? J Clin Oncol 2002; 20: 3761-3764.

11 Ooi E, Chapman S. An analysis of newspape reports of cancer breakthroughs: hope or hype? Med J Aust 2003; 179: 639-643.

12 Scheufele DA. Framing as a theory of media effects. J Commun 1999; 49: 103-122.

13 Neuendorf K. The content analysis guidebook. London, California, New Delhi: Sage, 2002.

14 Kitto SC, Chesters J, Grbich C. Quality in qualitative research. Criteria for authors and assessors in the submission and assessment of qualitative research articles for the Medical Journal of Australia. Med J Aust 2008; 188: 243246.

15 Lombard M, Snyder-Duch J, Bracken CC. Content analysis in mass communication: assessment and reporting of intercoder reliability. Hum Commun Res 2002; 28: 587-604.

16 Cohen J. Weighted kappa: nominal scale agreement provision for scaled disagreement or partial credit. Psychol Bull 1968; 70: 213-220.

17 Fleiss J. The measurement of interrater agreement. In: Statistical methods for rates and proportions. 2nd ed. New York: John Wiley, 1981: 212-237.

18 Richards L. Using N6 in qualitative research. 1st ed. Doncaster, Vic: QSR International, 2002.

19 Miles MB, Huberman AM. Qualitative data analysis: an expanded sourcebook. 2nd ed. London: Sage, 1994.

20 Toy M-A. Doctor's plea for a generation of los boys. The Age (Melbourne) 2001; 2 Feb: 6.

21 Perry L. Genetic clue to schizophrenia. The Australian 2004; 8 June: 3.

22 Robert S. New happy drugs needed. The Mercury (Hobart) 2006; 4 Mar: B05.

23 Weaver C, Chesterton A. Depression gene found Sunday Telegraph (Sydney) 2006; 26 Feb: 3.

24 Masanauskas J. Stigma buries common problem. Herald Sun (Melbourne) 1999; 18 Oct: 24

25 Dayton L. Australian researchers make schizophrenia breakthrough. The Australian 2009; 2 Jul: 7.

26 Chapman J. Disease cure hopes from book of life. Daily Mail (UK). Republished in: The Advertiser (Adelaide) 2001:13 Feb: 3

27 Smith D. Local team narrows search for key to bipolar trigger. Sydney Morning Herald 2003; 11 Sep: 3 .

28 Mitchell PB, Meiser B, Wilde A, et al. Predictive and diagnostic genetic testing in psychiatry. Psychiatr Clin North Am 2010; 33: 225-243.

29 Karg K, Burmeister M, Shedden K, Sen S. The serotonin transporter promoter variant (5HTTLPR), stress, and depression meta-analysis revisited: evidence of genetic moderation. Arch Gen Psychiatry 2011; 68: 444-454.

30 Hudson K, Javitt G, Burke W, Byres P. ASHG statement on direct to consumer genetic testing in the United States. Am J Hum Genet 2007; 81: 635-637.

31 Petersen A. Biofantasies: genetics and medicine in the print news media. Soc Sci Med 2001; 52: 1255-1268.

32 Moynihan R, Sweet M. Medicine, the media and monetary interests: the need for transparency and professionalism. Med J Aust 2000; 173: 631634.

33 Cook DM, Boyd EA, Grossmann C, Bero LA. Reporting science and conflicts of interest in the lay press. PLOS ONE 2007; 2: el266. 